Alternative fuels such as 'coal oil' mixtures were tried but not used extensively. Contrary to present British practice, the principal change was from oil firing to coal-fired equipment, and in household use from oil to gas. There were control organisationsa petroleum administrator and a 'solid fuel administrator', and as civilian fuel became short, rationing was developed. Judged by British standards, the measures adopted do not sound onerous. For example, the general consumer would experience a restriction of solid fuels to seven-eighths of normal use. Various steps to conserve fuel were enforced, such as the adoption of 'brownout' and 'dimout' rules, reduction of space heating and organisation of a fuel economy campaign.

Post-war conditions are expected to bring more efficient equipment in domestic practice. Where hydro-electric power is available, and off-peak current can be used to store heat, there will be more spaceheating by electricity. No great reduction of fuel consumption is anticipated, however, in view of the increased demand for improved amenities. No radical improvements in conventional equipment are ex. pected. New designs include the gas turbine, hot;air turbine and the heat pump for cooling and heating. The War has compelled increased interest in fuel education--enforced by the "advent of shortages and increases in the relative costs of fuel". In this respect conditions resemble those in Britain.

\section{Abnormal Solar Radiation on 75 Megacycles}

Messrs. S. E. Williams and P. Hands, of the Department of Physies, University of Western Australia, hay sent a long communication referring to observations made there of 'solar radio-frequency radiation $h$ a wave-length of 4 metres, using a Yagi aerial of moderate directivity, mounted on a polar axis. Measurements of the ratio of currents due to solarplus-receiver noise and receiver noise only, recorded with the dipole short-circuited, were made with a milliammeter in the anode circuit of the (linear) second detector. Later an oscillograph was used to secure a continuous record. Continuous observations were maintained for from three to five hours each day, during the passage of the large sunspot group having mean meridian passage on July $26 \cdot 7$ (G.M.T.) and the two following groups with mean meridian passage on August 2.4. On the basis of these observations they divide solar radio-frequency noise roughly into two components, one 'steady' or relatively slowly variable (Component I), the other abruptly variable (Component II). A striking example of the variation of the so-called Component II was observed on August 2, when it was estimated that this 'storm" involved changes in noise emission by 50-100 times in a few seconds.

These short-period variations during $03 \mathrm{~h} .14 \mathrm{~m} .10 \mathrm{~s} .-$ 03h. $29 \mathrm{~m}$. 10s. (approx. G.M.T.) corresponded with visual changes on the sun's disk as recorded on spectrohelioscope observations made by Watheroo Magnetic Observatory. A similar but less intense disturbance, during which the milliammeter showed increases in solar/receiver noise from 10 per cent to more than 150 per cent, was recorded on the same day between $04 \mathrm{~h} .51 \mathrm{~m}$. and $04 \mathrm{~h} .57 \mathrm{~m} .30 \mathrm{~s}$. (G.M.T.), when ionospheric equipment at Watheroo recorded a fade-out of intensity 4 (scale 1-9) during 04h. $45 \mathrm{~m}$.$05 \mathrm{~h} .00 \mathrm{~m}$., followed by a spectrohelioscope report of a faint prominence at $05 \mathrm{~h}$., indicating a flare at about $04 \mathrm{~h} .50 \mathrm{~m}$.
Messrs. Williams and Hands point out that since $75 \mathrm{mc} . \mathrm{s}$. radiation cannot penetrate regions where the electron density is greater than $10^{8} /$ c.c., which would be exceeded in the lower chromosphere, the correlation of solar noise generation with prominence activity seems probable. Further, as disturbances involving the emission of Component II are not necessarily accompanied by fade-outs, whereas chromospheric flares occurring within an hour or so of local apparent noon almost always produce fade-out effects, they suggest that correlation of Component II with flares would not be generally observed, but that coincidences between these phenomena would depend on the level at which increased excitation of the $H \alpha$ line occurs. This note of work at the University of Western Australia should be read in eonjunction with the communication by Dr. A. C. B. Lovell and C. J. Banwell on p. 517 of this issue of Nature.

\section{Survey of British Somaliland}

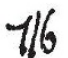

SugGesmons for a general survey of British Somaljand te made before the War in connexion with fy upplies, soil erosion and other problems Af cting theneral development of the country, but w. $\mathrm{Not}$ put into execution at the time. The Military dovernment of the Protectorate has now issued a report outlining surveys made and data collected from 1942 onwards, and recording the work of a special department under Major J. A. Hunt from its inception in August 1943 until December 1944 (Report on General Survey of British Somaliland, 1944. Pp. $12+17$ charts. (Burao: Gov. Press, 1946.) 3s. 6d.). The programme of work of the department conforms roughly to that advocated by Dr. E. B. Worthington in "Science in Africa", and starts with the accurate collection of meteorological and geological data, followed by a soil survey, plant and then animal ecology. The preliminary results are illustrated in a series of maps and diagrams published with the report, covering rainfall, plant ecology and tribal migrations and potential developments in minerals, water, agriculture and roads. The General Survey has now been recognized in principle by the Colonial Office, and funds have been provided under the Colonial Development and Welfare Act to finance an "economic survey and reconnaissance" with a programme extending until 1950. The water and mineral surveys will be made by two specialist geolog. ists. on arrival and may take up to two years. Altitude, rainfall and plant ecology are closely interrelated, and rain crop cultivation can only be considered and tested in a limited area above 4,000 ft. Sites are recommended for irrigation gardens and date plantations, and a new road from Berbera to EI Afwein and Hudun is recommended as being situated on the most direct route to the eastern part of the Protectorate with no difficult escarpments to surmount. The Military Governor points out in his introduction to the report that the political and economic life of the Protectorate and neighbouring countries is threatened by increasing migrations of Somali tribes, who will be unable to find subsistence in their own country if conditions continue to deteriorate. The report strongly recommends publication of reports and specialist papers to stimulate interest in research, and also that when the two years survey of water and minerals has been carried out, the Survey should organise a technical library and laboratory in Burao, which is the natural centre for any scientific work in the Protectorate. 